\title{
Articles
}

\section{THE MODEL OF DEMAND FOR PRODUCTION FACTORS IN AGRICULTURE}

\author{
JUSTYNA GÓRAL \\ WEODZIMIERZ REMBISZ
}

\begin{abstract}
This publication is theoretical in nature. It attempts to determine a hypothetical relation between the supply of agricultural production determined by the given demand for it on the one hand and the demand for factors involved in the production on the other. It is included in one model of reasoning with the use of regularities and coefficients known in microeconomics. In particular, the demand, supply and production elasticity coefficients were used. The starting point is assumptions resulting from the demand and three-factor function of production and about rational choices of farm producers. The hypothesis that the relation between supply of production for the demand for it and demand for production factors is determined by changes in production efficiency was positively verified by means of theoretical and formal analysis. This was proved by reference to price elasticity of production and supply and price elasticity of demand for production factors in relation to a product. This is an attempt to fill a research gap in this field.
\end{abstract}

Keywords: price elasticity of supply, factor elasticity of production, elasticity of demand for production factors.

JEL codes: D20, D24, Q11, Q12.

\footnotetext{
Justyna Góral, PhD, Warsaw School of Economics, Collegium of Socio-Economics, Department of Public Administration; ul. Wiśniowa 41, 02-520 Warsaw, Poland (justyna.goral@onet.pl).

ORCID iD: 0000-0003-1248-579X.

Włodzimierz Rembisz, PhD, DSc, ProfTit., Institute of Agricultural and Food Economics - National Research Institute, Department of Agricultural Markets and Quantitative Methods; ul. Świętokrzyska 20, 00-002 Warsaw, Poland (w.rembisz@gmail.com). ORCID iD: 0000-0001-9941-3398.
} 


\section{Introduction}

The belief that there is a specific relation between changes in demand for agricultural products and changes in demand for production factors involved in their production seems to be unquestionable. This is intuitively obvious. However, a question arises whether it has any scientific grounds. The easiest way to prove it could be to formulate a question about the relation between the elasticity of demand for product and the elasticity of demand for production factors. More precisely, this question can be limited to the relation between price elasticities of demand for a product and for production factors. It also seems obvious that the relations between these elasticities in two markets, i.e. the market of products and the market of production factors, do not need to be proportionate, i.e. the elasticity of demand for agri-food goods does not need to correspond to the same elasticity of demand for production factor(s). Moreover, they can not only differ, but also change more or less proportionally in relation to each other. These are both important cognitive and practical issues, e.g. to forecast the sustainability of tasks regarding the production and means in relation to the engagement of production factors, to forecast the reality of production results, etc. Following this way of thinking, an equally, if not more, an important question arises: what does the relation between these elasticities and its changes depend on? Intuition and knowledge of economics suggest that this should depend on the production efficiency and its changes. However, a scientific question and also a task is how to demonstrate it or prove it. These questions form a basis of this theoretical article.

The theoretical analysis used certain generalisations and abstractions as to the essence of considered relations and values. It has been assumed that the demand and its determinant, namely, the price elasticity of demand for the product (production) are pre-defined values being beyond the mainstream scope of this analysis. The supply determined by its price elasticity is adapted to the demand, naturally, in the opposite direction to the price elasticity of demand. The approximate equality of these price elasticities of demand and supply is an essential starting point for further analysis. For this price elasticity of supply, as a resultant value, the price elasticity of demand for production factors has been determined. These are typical factors for the three-factor production function characteristic of agriculture, namely, the capital, labour and land factors. A link ${ }^{1}$ for this relation of two price elasticities of supply of production and demand for production factors is the production elasticity. The production elasticity is, in fact, a relative measure of production efficiency, which refers to the intuitive approach indicated at the beginning. This reasoning is based on the concept of elasticity. Firstly, it was based on the production elasticity, the concept derived directly from the production function, and on the concept of elasticity of demand and supply derived from specific functions of demand and supply in a general form. The formal essence of these factors is the same.

In order to ensure that this description of market relations by means of these elasticity factors reflects real economic processes, the grounds for agricultural

\footnotetext{
${ }^{1}$ This is something similar to the differential, as in a car engine.
} 
producer's choice were taken into account. The point here are assumptions on the rationality of choice of the producer who maximises their goal function, i.e. income, as a price taker ${ }^{2}$, i.e. under the conditions of competitive equilibrium. Then, there are specific conditions for the maximisation relative to the level of application (engagement) of the given production factor in relation to its remuneration for the revenue. This is extremely important as the point here are not the maximum levels of engagement of factors, but their engagement which is as efficient as possible, implicitly in relation to their prices or remunerations. The authors treat it as an assumption and a condition which is to some extent necessary, and not as a subject of enquiries. This also means that the subject of analyses is not to determine the relations between these factors of elasticity of demand (in fact, in the market of products and in the market of factors), but the economic mechanism shaping this relation. This is the main objective of enquiries in the article and its added value.

The analysis used a relatively simple analytical approach related to the differentiation of production and demand functions. Mathematical formulas and symbols were used to structuralise the problem and to provide evidence of the research hypothesis. The formulas derived are not intended for direct empirical use, but may be subject to such verification when supplemented and specified, e.g. as regards the dimensionality or expression of expressed values. The objective is only an inductive and logical argumentation or verification of the hypothesis based on the original approach to the mechanism shaping the relation between the price elasticity of supply of products to the price elasticity of demand for production factors necessary for obtaining this supply (production).

It was hypothesised that the element differentiating the relation between the elasticity of supply of product (production) for the given elasticity of demand for these goods and the elasticity of demand for production factors is the production elasticity in relation to production factors. It is a measure of a relative production efficiency and is the most important in this relation. The formal demonstration of verity of this assumption will be a positive verification of this hypothesis.

\section{Reference to literature}

In theoretical terms, the problem of the ratio of demand for and supply of agricultural products to demand for production factors has been dealt with by several outstanding researchers in the field of economics of agriculture and economy (e.g. Z. Griliches, J.P. Houck, M.E. Ryan, G.T. Jones, A.J. Rayner, K. Salhofer). The conducted arguments and theoretical analyses were characterised by the high formal and mathematical advancement of approaches. More authors attempted to estimate these relations or even dependencies empirically based on specific econometric models (G.S. Latta, D.M. Adams, C.R. Shumway, P.A. Villezca-Becerra, P. Vukadinović, A. Damnjanović, J. Kristić-Randić). The authors mostly refer to

\footnotetext{
${ }^{2}$ This means that the producer cannot increase income as an objective of economic activity through the rise in prices of products, by adjusting them to his production costs.
} 
the approach presented by J.P. Houck (1985), who analysed the impact of changes in the production elasticity in relation to production factors on the elasticity of demand for these factors for the specific supply function. He carried out a theoretical analysis with some hypothetical scenarios regarding the differentiation and changes in the production elasticity as a measure of relative production efficiency. Some ideas from his study were reflected in this approach in this article. This refers, in particular, to mutual relations between the elasticity of supply of product and the elasticity of demand for production factors. Here, the formal and mathematical aspect is also excessively complicated. An equally important point of reference for this issue in literature is the approach presented by Z. Griliches (1959). He analysed the issue of demand for production factors in general theoretical paper terms, and then in disaggregated terms, using differentiable identities or demand functions. This approach has also been referred to in this. Z. Griliches introduced some elements of analysing how changes in the production efficiency impacted demand functions, but with no formal evidence. A.J. Rayner (1970) presented a theoretical approach to the aggregated elasticity of supply of product and elasticity of demand for factors, based on supply and demand functions with the declining distribution of delays. Inspired by a valuable contribution to science made by Z. Griliches, he referred to the theory of demand for production factors and the elasticity of this demand. The publication by this researcher inspired the authors of this article, as did the studies by Z. Griliches.

However, in empirical terms, using specific econometric and statistical models, the problem of demand for production factors in relation to demand for and supply of products has been the subject of greater attention and frequent analyses and studies. F. Bonnieux (1989), when analysing the demand of farm producers for production factors, used the estimable translogarithmic production function in regional terms. He showed the significant substitutability of demand for production factors. In the context of our approach, the author included in the production function HicksAllen elasticities and also four production factors: materials, capital, land and labour. However, he focused on the price of factors as variables rather than on demand and supply, as it was in this article. He referred to the substitutability of all pairs of production factors except, which is quite surprising, land and capital. H.P. Binswanger (1974), R.E. Lopez (1980) and S.M. Capalbo (1985) dealt with similar issues. J. Higgins (1986) applied an approach based on the profit function of farm producers so as to estimate the elasticity of supply of production and elasticity of demand for production factors. He presented both compensated and uncompensated data on those elasticities. This was a contribution to some identification of changes in those elasticities. In the following years, the issue of elasticity of demand for production factors in relation to the elasticity of supply of products, has been even more mathematicised, an example of which is the publication by A.R. Maligay and F.C. White (1989), as well as by N.V. Shende and K.J. Shinde (2010). P. Kumar et al. (2010) conducted extensive empirical studies on the dynamics of supply and demand regarding the Indian agricultural sector. They estimated the demand for production factors and the elasticity of supply of products from major crops in India. The pub- 
lication by F.G. Santeramo (2014) is more general. It contains extensive literature studies on the assessment of demand for factors and its elasticity. The author cited the major aspects of production theory in order to introduce various types of elasticity of demand for production factors into this issue. Thus, he developed the aspects of production theory and producer's choice. In turn, A. Pagoulatos and D.L. Debertin (2015), when presenting the analytical approach to the relations between production function parameters, elasticity of demand and production, assumed that the volume of final agricultural production was a random variable. Then, they referred to the Gauss-Markov theorem. The studies by these authors introduced several previously unrecognised relations between the production elasticity and elasticities of supply and demand in the production theory. A common feature of these studies is sometimes the excessive complexity of formal and mathematical argument, which slightly obfuscates the essence of economic problem. The essence of this problem is a mechanism defining the relation between the elasticity of supply of product and the elasticity of demand for production factors.

\section{Revenue vs. remuneration and engagement of production factors}

The starting point for the analysis is the basic and general relation between demand and supply. In the convention of circular flow, demand is represented by consumers as buyers while supply adapted to this demand is represented by producers. Revenues $^{3}$ of these producers result from expenses of buyers (we assume that they are not differentiated by price-related tax). This can be illustrated in the following way ${ }^{4}$ :

$$
x \cdot p_{y}^{*} \Rightarrow y \cdot p_{y}^{*}
$$

for: $p_{x}=p_{y}^{*}=p_{y}$

where:

$x \quad-$ product $^{5}$ on the demand side;

$y \quad$ - the same product on the supply side;

$p_{x} \quad$ - price of product paid by the buyer;

$p_{y}$ - price of product on the supply side (in fact, we have: where $t-\operatorname{tax}$ );

$p_{y}^{*}-$ equilibrium price of product.

\footnotetext{
${ }^{3}$ At this level of generalisation, we do not differentiate them to potential or actual.

${ }^{4}$ This can also be expressed at the lower level of generalisation and abstraction as:

$$
\sum_{i}^{n} x_{i} \cdot p_{x i} \Rightarrow \sum_{i}^{n} y_{i} \cdot p_{y i}
$$

where: $N$ - quantity of the same products on the supply and demand sides, $x_{i}$ - product on the demand side (bought) from 1 to $n, y_{i}$ - the same product on the supply side from 1 to $n, p_{x i}$ and $p_{y i}$-prices of individual products (to some extent expected by the buyer and seller), however this detailed expression does not change the essence of reasoning, only structures can be taken into account.

${ }^{5}$ As a certain microeconomic abstraction, at this level of generalisation, the production provides products, for the buyer the product becomes the good when it is usable and bought, it is a reference to the Jevons's approach.
} 
As it may be observed, producers' revenues are directly shaped (implied) by consumers' expenses, which is an obvious expression of regulatory function of the market, as producers produce what buyers demand. This is assumed on a general basis and for the purpose of confirming that producers' revenues are verified by consumers' choices. This is an assumption of rationality ${ }^{6}$. The equation (1) is just an input assumption.

On the same basis of reasoning, it has been assumed that producers' revenues are the only source of financing of their inputs (engagement) of production factors. Naturally enough, it means that producer's choices are conditioned by consumer's choices (it is about the regulatory function of market). In other words, they result from market signals and are not distorted, for example, by interventions, as we did not take into account support and subsidies, but also taxes. This also means that we assume that the price of product is the only (essential) source of information for producers, but initially also for consumers (implicitly, it can be assumed that this price is, to some extent, related to costs of obtaining the given product for producers and to the usability in the case of consumers).

By introducing the equation of costs of engagement of production factors in comparison with revenues, the following relation has been achieved:

$$
y \cdot p_{y}^{*}=L \cdot p_{L}+K \cdot p_{K}+Z \cdot p_{Z}
$$

where: $L, K, Z$ - levels of engagement of production factors, i.e. labour factor, capital factor and land factor, within the meaning of theory of production factors (Tomczak and Woś, 1983) and production function, other designations - as above.

According to this equation, the level of engagement of those production factors is determined by revenues, but also by the remuneration of each production factor. Each product on the right side of the above equation (2) is the cost of engagement (input) of the given factor ${ }^{7}$. We can relate each of them to a limitation which market revenue is (from sales of production = supply).

Based on each of these products, according to the theory of producer's choice, relations defining the possible level of remuneration of the factor were derived in the same way as its engagement which will be discussed later. Naturally, at the given revenue. This assumption is similar to the conditions of competitive equilibrium. This entails the principle of zero profits and there are no economic rents (as the remuneration of the given production factor results from its productivity at given prices

\footnotetext{
${ }^{6}$ Naturally, in addition, it should be assumed here that the producer has only an impact on the production volume $\frac{\partial y}{y} \neq 0$, and does not have any impact on the price: $\frac{\partial p}{p}=0$ as an entity in the market with comp etitiveequilibrium. In practice, revenue $y \cdot p>0$ is a function of production changes and volumes (supply) as well as price changes. The latter more indirectly entail changes in demand in the short term concerned.

${ }^{7}$ Another issue is to include this in accounting records and cost accounting. Here, the reasoning is conducted at the level of aggregation and generalisation specific to microeconomics.

${ }^{8}$ This is included in each advanced book on microeconomics regarding the theory of producer or the theory of his optimal choice.
} 
of products and producers are in equilibrium, i.e. they substituted factors with the lower productivity/price ratio with those which are better in this respect). Without elaborating on this issue, we obtain the following relations based on which we can determine the remuneration of factors for condition (2). Thus, we have:

$$
p_{L}=\frac{y \cdot p_{y}^{*}}{L}, \quad p_{K}=\frac{y \cdot p_{y}^{*}}{K}, \quad p_{Z}=\frac{y \cdot p_{y}^{*}}{Z}
$$

Thus, the remuneration of these production factors results from their average revenues. We assume that we deal with the conditions of competitive equilibrium for which the product price is a variable from the market and independent of the producer. This price, by assumption, reflects information related to the level of rarity and usability of product to the buyer and to market-verified unit costs of producing products. Naturally, it was assumed that these remunerations do not differ from market prices and remunerations of these production factors in other applications thereof. Moreover, this remuneration is induced by these prices of factors. This assumption implies an effective allocation of production factors, to which we do not refer here. We mention it so as to assume that such remuneration of abovementioned production factors can be adopted as being objective ${ }^{9}$ and as a basis for determining the demand for the given production factor. This last conclusion is the most important for further analysis. This can be demonstrated (proved) as before. The relations determining the engagement of production factors for baseline conditions (2) and for their remunerations (3) are therefore as follows:

$$
L=\frac{y \cdot p_{y}^{*}}{p_{L}{ }^{\prime}}, \quad K=\frac{y \cdot p_{y}^{*}}{p_{K}{ }^{\prime}}, \quad Z=\frac{y \cdot p_{y}^{*}}{p_{Z}}
$$

where: $p L, p K K^{\prime}, p Z^{`}$ - actual remuneration of production factors.

The above formulas (4) are, in fact, the most basic equations of demand for production factors concerned, with the level of revenues assumed in (2) - implicitly for the given demand for production for which those factors were involved. This refers to the given production cycle (hence, the t-time subscript was omitted at the values of sizes of engagement of the given factor). This shows the essence of these important relations in general. Their interpretation is obvious. The increase in the remuneration of the given factor, implicitly induced by the rise in its market price and the increased remuneration in other applications leads to a reduction in its engagement. This does not need to be justified ${ }^{10}$. The source of financing for

\footnotetext{
${ }^{9}$ This may be distorted by specific subsidies and direct payments to e.g. a unit of land or capital factor and other forms of support or limitations in the mobility of production factors.

${ }^{10}$ The increase in demand for the land factor in non-agricultural applications increases its price and the need to increase its remuneration in agriculture, i.e. de facto the need to increase its productivity and revenues. However, the price of land in agriculture breaks away from this rule due to competitive non-agricultural and non-production applications and due to the capitalisation of subsidies. The same applies to the labour factor. The increase in its remuneration in non-agricultural sections necessitates the increase in its productivity also by means of decreasing its engagement in agriculture.
} 
the increased remuneration of the production factor can only be an increase in revenue from the given factor as in (3). The relations between these remunerations of factors are also important, i.e. in our case - denominators in the above formulas (4). They are important for determining factor-based relations.

When we assume, in the given period, the amount of revenue as a specific value, i.e. either a given value or a constant value (i.e. $y \cdot p_{y}=R=$ const), we can relate changes in the size of engagement and remuneration of the production factor to each other (using the principle of differentiation). As a result, we have simple equations of demand for factors where changes in the engagement of production factors are referred to changes in their remunerations (increased remunerations of labour and land factors and decreased remuneration of capital factor) for revenues concerned:

$$
\frac{\Delta L}{\Delta p_{L}}<0 \text { and } \frac{\Delta Z}{\Delta p_{Z}}<0 \text { for } \Delta p_{L}>0, \Delta p_{Z}>0
$$

and also:

$$
\frac{\Delta K}{\Delta p_{K}}>0 \text { for } \Delta p_{K}<0
$$

With the assumed relative reduction in the price of capital factor, when compared to other production factors, there are changes, known in the economics of agriculture (Woś and Tomczak, 1983), as regards the structure of production factors involved for achieving given revenues .

$$
\frac{\Delta L\left(\Delta p_{L}\right)}{\Delta K\left(\Delta p_{K}\right)}<0 \text { and } \frac{\Delta Z\left(\Delta p_{Z}\right)}{\Delta K\left(\Delta p_{K}\right)}<0
$$

Also, or above all, the result is the growing average productivity (profitability) as a basis for increasing the remuneration of labour and land factors, however, the relative reduction in the productivity (profitability) of capital factor: ${ }^{11}$

$$
\Delta\left(\frac{y \cdot p}{L}\right)>0 \quad \text { and } \quad \Delta\left(\frac{y \cdot p}{Z}\right)>0
$$

This is reflected in the actual demand for production factors, that is why we dedicate our attention to it and we elaborate on it in our further reasoning.

\footnotetext{
${ }^{11}$ The increase in the engagement of capital factor is burdened with substitution functions in relation to the decrease in labour and land factors.
} 


\section{Demand for production factors in the goal function of farm producer}

The equation (2) corresponds to the expression of goal function of the farm producer: ${ }^{12}$

$$
\sum_{i}^{n} y\left(p_{y}\right) \approx R^{*}=\{K, L, Z, n\}
$$

This means that the producer tries to increase revenue in relation to involved tangible production factors ( $K, L, Z$ described above) and intangible factors (n) or vice versa, what we assume here - to minimise the cost of involving factors for obtaining given revenue $R^{*}$, at the given price of the product (thus in parentheses).

For the given revenue (we adopt this as a limiting assumption just like previously for the given demand) as a constraint with regard to the use of factors (within the meaning of source of financing and reproducing their use in the given production and commercial cycle), we therefore have: ${ }^{13}$

$$
y_{i} \cdot p_{i} \Rightarrow R^{*}=K \cdot p_{K}+L \cdot p_{L}+Z \cdot p_{Z}
$$

Therefore, the level of remuneration of the factor involved for the given revenue is determined by the following relation: ${ }^{14}$

$$
\frac{d y}{\partial K}=p_{K} \quad \text { and } \quad \frac{d y}{\partial L}=p_{L} \text { and } \quad \frac{d y}{\partial Z}=p_{Z}
$$

Therefore, for given remunerations (prices) of production factors and using equation (10), we have the conditional demand for the given factor (e.g. capital factor) defined as:

$$
K=\frac{R^{*}}{p_{K}}-\frac{L \cdot p_{L}}{p_{K}}-\frac{Z \cdot p_{Z}}{p_{K}}
$$

If the demand was referred to one factor in the absence of demand for other factors (hypothetical unrealistic assumption, but it highlights the problem), it could be illustrated in the following way:

$$
K=\frac{R^{*}}{p_{K}} \quad \text { and } \quad L=\frac{R^{*}}{p_{L}} \quad \text { and } \quad Z=\frac{R^{*}}{p_{Z}}
$$

\footnotetext{
${ }^{12}$ Assuming a functional relation, where no variable is stochastic and prices of product in the given period are constant.

${ }^{13}$ If prices of factors were introduced in alternative applications, this can be expressed as alternative costs, however, this is unnecessarily complicated and deviates from reality, although interesting, with this reasoning we have here remunerations of factors, i.e. actually incurred costs.

${ }^{14}$ As a result of solving the Lagrange conditional function (Rembisz and Sielska, 2013) for these conditions the producer is in equilibrium, maximising his goal function, prices of products are the same for the productivity of each factor, i.e. as the constant, they are omitted in differential calculus.
} 
In this case, the demand would result only from the budgetary limitation (given revenues) and the price of factor, i.e. in fact the relative price of factor concerned, i.e. its relation to revenue. As we know, support schemes break this limitation, which may change the assumption on reasonable selection.

The approach by Z. Griliches (1959) is similar, where for a specific analytical form of function (on example of capital factor):

$$
K=p_{K} \cdot p^{b}
$$

and for the supply function of capital factor:

$$
K=p_{K}^{d}
$$

where:

$b>0,0<\mathrm{d}>1-$ parameters of function of the price of product and price of capital factor;

$p$ - price of product, other designations as above.

The comparison of both above-mentioned functions relates the price of product and the price of factor to the demand for it, which is further analysed.

\section{Elasticity of production and supply vs. engagement of production factors}

Taking into account the assumption of production function in static terms, neoclassical assumptions about convexity, continuity and smoothing and referring to the homogeneous product, the production function for the above-mentioned reasoning will take the following form:

$$
y=f(K, L, Z, \ldots, n)
$$

where: designations as for (9).

Assuming implicitly the conditions of competitive equilibrium, we assume, as above, that prices of product $\mathrm{p}$ are given for the producer and remunerations (prices) of factors $\left(p_{K}, p_{L}, p_{Z}\right)$ are determined according to (11) and (3). With these assumptions, a single farm producer, maximising his income (profit), in accordance with the above-mentioned principles of microeconomics, compares the marginal productivity of each factor to the ratio of its remuneration to the price of product $(p)$. We refer here to (Houck, 1985). Thus, the following equation can be derived:

$$
\frac{\partial y}{\partial K}=\frac{p_{K}}{p_{y}} \quad \text { and } \quad \frac{\partial y}{\partial L}=\frac{p_{L}}{p_{y}} \quad \text { and } \quad \frac{\partial y}{\partial Z}=\frac{p_{Z}}{p_{y}}
$$


This corresponds to the classic condition of profit maximisation, i.e. the equality of marginal revenue and marginal cost of applying the factor in question: ${ }^{15}$

$$
\partial y \cdot p=\partial L \cdot p_{L} \quad, \quad \partial y \cdot p=\partial K \cdot p_{K} \quad, \quad \partial y \cdot p=\partial Z \cdot p_{Z}
$$

With these grounds for producer's choices, defined according to microeconomics, in further analysis we can use the importance of elasticity factors. They are easier to interpret in theoretical analysis and practical implications when it comes to relations of demand for production factors. The first are production elasticities in relation to the production factor. To some extent, they illustrate the production efficiency in terms of elasticity of changes in the size of products (including supply) when compared to changes in the engagement of production factor concerned:

$$
\alpha_{K}=\frac{\partial y}{\partial K} \cdot \frac{K}{y} \quad \text { and } \quad \alpha_{L}=\frac{\partial y}{\partial L} \cdot \frac{L}{y}, \quad \text { and } \quad \alpha_{Z}=\frac{\partial y}{\partial z} \cdot \frac{z}{y}
$$

The coefficients express $\alpha_{x}$, as we know, the percentage change in production in relation to one percent change in the engagement of identified factor: labour; capital; land. These coefficients, as regards their changes, depend on a specific form of analytical production function, from which they can be derived, e.g. for the power function known as the Cobb-Douglas production function they are cong stant. In further analysis, due to its theoretical rather than econometric and statistical nature, we do not make any specific assumptions about their size, except for a few limitations. They result, of course, from the assumptions on the productivity adopted in the analysis of production factors, and specifically their changes. It is clear to assume that these factors are rationally used (they are in the sphere of rationality in the classical production function), i.e. we have at least:

$$
\alpha_{L}>0 \text { and } \alpha_{K}>0 \text { and }>0
$$

As we know, the sum of production elasticity coefficients in relation to the level of engagement of production factors is defined by the so-called scale effect:

$$
\sum_{i}^{n} \alpha_{X}=\omega, \quad(X=L, K, Z)
$$

The scale effect determines the percentage change in the production when compared to one percent change in the engagement of all production factors. These scale effects, as we know, can be decreasing, growing or constant. In this case, we assume, in accordance with the views expressed in the literature of agricultural economics, that constant and growing effects are dominant, and namely:

$$
\omega=1 \quad \text { and } \quad \omega \leq 1
$$

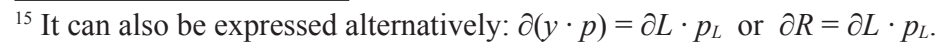


Further, we focus on the case of constant scale effects: $\omega=1$. We will point to the possibilities of interpreting the relation of changes in the production (supply) and demand for production factors based on these elasticity factors, treating them as a measure of relative production efficiency, which is the main subject of study in this article.

It can initially be assumed that the production elasticities in relation to production factors are shaped by changes in the application of the factor concerned (Houck, 1985), which can be expressed by means of the following formulas: ${ }^{16}$

$$
\tau_{L}=\frac{\partial \alpha_{L}}{\alpha_{L}}: \frac{\partial L}{L}=\frac{\partial \alpha_{L}}{\partial L} \cdot \frac{L}{\alpha_{L}}, \quad \tau_{K}=\frac{\partial \alpha_{K}}{\partial K} \cdot \frac{K}{\alpha_{K}}, \tau_{Z}=\frac{\partial \alpha_{Z}}{\partial Z} \cdot \frac{Z}{\alpha_{Z}}
$$

These relations, as elasticity coefficients, explain the percentage change in the value of production elasticity in relation to the given factor under the influence of one percent change of its application. Similarly, this can be referred to substitution relations, i.e. how the production elasticity in relation to the given factor changes under the influence of other (substitution) factor. For example:

$$
\tau_{L / K}=\frac{\partial \alpha_{L}}{\partial K} \cdot \frac{K}{\alpha_{L}} \quad \text { and } \quad \tau_{L / Z}=\frac{\partial \alpha_{L}}{\partial Z} \cdot \frac{Z}{\alpha_{L}}
$$

Therefore, it is shown how the elasticity is going to change under the influence of change in the application of the given (isolated) or second substitution production factor, which are included in the production function. These are, in particular, relations of relative substitution between them, i.e. production factors to obtain the same level of production and for given prices to obtain the same level of revenue. For example, $\tau_{L / K}$ measures how the production elasticity changes in relation to the laa bour factor due to the increased application of capital factor, just like $\tau_{L / Z}$ refers the production elasticity in relation to the labour factor to changes in the application of land factor (implicitly to the quotient of land factor to labour factor). In fact, these coefficients are the second direct and mixed derivatives of basic function. In economic sense, they can inform about the change in the production elasticity under the influence of changes in the application, also in substitution relations, of production factors and the other way round. Therefore, from a planned change in the production we can achieve a necessary change in the application of production factor at the given production elasticity in relation thereto - implicitly as a measure of efficiency of applying the given factor and in relation to the substitution factor (this requires further inquiries and explanations, which have been omitted at this stage). Therefore, we can determine the actual demand for factors for the given (projected) production, or vice versa, we can project productions and supply from the factors concerned, taking into account their substitutability. This is a relatively little known approach to analysing mutual relations of changes in the production with respect to changes in production factors.

${ }^{16}$ More universally, it can be presented as follows:

$\tau_{i j}=\frac{\partial \alpha_{i}}{\partial X_{j}} \cdot \frac{X_{J}}{\alpha_{i}}$ or $\tau i=\frac{\partial \alpha_{i}}{\partial X_{i}} \cdot \frac{X_{i}}{\alpha_{i}}$ for: $i, j=1,2 \ldots, n$, where $x_{i}, x_{J}, \ldots x_{n}$; levels of engagement of production factors, designations and idea are provided after Houck (1985). 
This can be combined with the elasticity of supply, connecting it more with the market. With the given changes in the prices of agricultural product, the elasticity of supply is implicitly in an appropriate relation to the elasticity of demand for these goods. This, in turn, affects relations of changes in the production to changes in production factors, i.e. production elasticity, as we wrote above. Therefore, let us focus on the elasticity of supply. The basic formula for the price elasticity of supply in general terms is as follows:

$$
\alpha_{y}=\frac{\partial y}{\partial p_{y}} \cdot \frac{p_{y}}{y}
$$

where: $\alpha_{y}$ - price elasticity of supply of a product.

After transformations and taking into account the following formulas: (7), (11) and (12), we receive the equation in relation to the given factor involved as: ${ }^{17}$

$$
\alpha_{y}=\alpha_{L}\left\{\frac{\partial L}{\partial p_{y}} \cdot \frac{p_{y}}{L}\right\} \quad, \alpha_{y}=\alpha_{K}\left\{\frac{\partial K}{\partial p_{y}} \cdot \frac{p_{y}}{K}\right\} \quad, \alpha_{y}=\alpha_{Z}\left\{\frac{\partial Z}{\partial p_{y}} \cdot \frac{p_{y}}{Z}\right\}
$$

The expression in parentheses in each of these formulas is, in fact, the elasticity of demand for the given factor, relative to the price of product at the given production elasticity relative to that factor. Thus, we have the elasticity of demand for the labour factor, capital factor and land factor in relation to the prices of products (buyingin prices), at the given production elasticity relative to these factors (as a measure of relative efficiency). We can describe this as factor-based production flexibilities at the given prices of product. In fact, their changes determine the relation between the elasticity of supply of the product and the elasticity of demand for production factors. Naturally, the rise in the prices of product must lead to the increase in demand for the given production factor, but this depends on the production elasticity relative to this factor. This measure of efficiency in fact differentiates changes in the market of products in relation to changes in the market of production factors. As it has been assumed at the beginning of the assumption, the nature of this elasticity may vary. Here, we assume whether we consider this issue in static terms. By revoking this assumption, it can, of course, be assumed that the demand for production factors described by means of price elasticity of demand for them in relation to the prices of products (directly linked to the price elasticity of supply) will change just like the value of the production elasticity coefficient relative to the given factor. Different scenarios are possible here, but we will not be considering them further on.

Consequently, the price elasticity of demand for the production factor can be expressed as:

$$
\varepsilon_{L}=\frac{\partial L}{\partial p_{y}} \cdot \frac{p_{y}}{L} \quad, \quad \varepsilon_{K}=\frac{\partial K}{\partial p_{y}} \cdot \frac{p_{y}}{K} \quad, \quad \varepsilon_{Z}=\frac{\partial Z}{\partial p_{y}} \cdot \frac{p_{y}}{Z}
$$

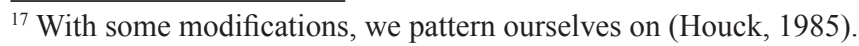


Thus, the above relations (25), (26), (27) may be expressed, from the viewpoint of the supply effect for labour and capital factors, as:

$$
\alpha_{y}=\alpha_{L} \cdot \varepsilon_{L} \quad, \quad \varepsilon_{L}=\frac{\alpha_{y}}{\alpha_{L}} \quad \text { and } \quad \alpha_{y}=\alpha_{K} \cdot \varepsilon_{K} \quad, \quad \varepsilon_{K}=\frac{\alpha_{y}}{\alpha_{K}}
$$

and similarly for the land factor (although in real terms, it is a certain simplification with respect to this factor):

$$
\alpha_{y}=\alpha_{Z} \cdot \varepsilon_{Z} \quad \text { and } \quad \varepsilon_{Z}=\frac{\alpha_{y}}{\alpha_{z}}
$$

Therefore, the elasticity of supply of the product depends on the production elasticity relative to the given production factor and on the elasticity of demand for it (i.e. the given production factor). The price elasticity of demand for the production factor $(\varepsilon)$, being of our interest, is proportional to the price elasticity of supply and inversely proportional to the production elasticity relative to the production factor as a measure of, in fact, relative efficiency.

The relations occurring here are mutual and fit into the known approaches to these elasticity coefficients. They establish significant relations in the process of management under market conditions, including when the farm producer is a price taker and is reasonable as to the choice of level of application of production factors, since it is assumed that they are remunerated according to their average and marginal revenues. Here, the source of market information is the price of product determining the elasticity of supply of the product and the elasticity of demand for the production factor. This is combined within the factor-based production elasticity.

The production flexibility relative to factors is, naturally, of key importance. Its evolution and changes are determined by: the price elasticity of supply of the product and the price elasticity of demand for production factors. It is clear that the increase in the production elasticity, i.e. in fact, the improved efficiency, results in the increased price elasticity of supply and reduced price elasticity of demand for the production factor (for its given remuneration specified at the beginning of analysis). In fact, it can be presented as follows:

$$
\alpha_{L}=\frac{\alpha_{y}}{\varepsilon_{L}} \quad, \quad \alpha_{K}=\frac{\alpha_{y}}{\varepsilon_{K}} \quad, \quad \alpha_{Z}=\frac{\alpha_{y}}{\varepsilon_{Z}}
$$

This clearly improves all observable economic indicators of agriculture, such as profitability, viability and, in general, the economic situation of farm producers. However, in cognitive terms it is another evidence for the fundamental importance of production efficiency for real processes of management (in this study - as relations between the market of goods and the market of production factors involved in their production). The above-mentioned issues fall within the scope of microeconomics and modern agricultural economics (neoclassical approach). 


\section{Summary}

By logical and formal reasoning, the adopted hypothesis has been positively verified in the deductive theoretical and neoclassical approach. Under the conditions of rational producers' choices for the given demand condition, the mechanism differentiating the ratio of elasticity of demand for agricultural products to the demand for production factors (as a result of the first elasticity) is related to the factors productivity - measured by the production elasticity, more precisely the factor-based production elasticity. Changes in this production elasticity, e.g. its improvement reduces the elasticity of demand for factors to achieve the given elasticity of supply ${ }^{18}$. This is important for the efficiency of processes of management. This clearly reduces costs (in terms of increasing the application of factors) of meeting the given demand for agricultural products. As a result, it further reduces production costs, increasing the profitability and viability in agriculture. This does not require any special evidence, as the coefficients and relations analysed in the article are the basis for them, i.e. for profitability ${ }^{19}$. In a formal sense, we introduced new coefficients and relations, useful in the in-depth analysis of management efficiency in the agricultural sector. This reasoning did not include subsidies and other forms of support, adopting them on a ceteris paribus basis. Expressing it as a variable requires a separate analysis, but it can be initially assumed that it will not change the idea and relations derived from this reasoning.

\footnotetext{
${ }^{18}$ This can also be expressed that the factor-based production elasticity, i.e. the response of production to changes in the level of application of the production factor is proportional to the price elasticity of supply and inversely proportional to the elasticity of demand for the factor in relation to the price of product.

${ }^{19}$ Another issue is the possible empirical analysis of sources of changes in the profitability of in production costs, and here - reference to the analysed elasticity coefficients, including, in particular, the production flexibility in relation to production factors, causality can be examined here.
} 


\section{References}

Binswanger, H.P. (1974). A cost function approach to the measurement of elasticities of factor demand and elasticities of substitutions. American Journal of Agricultural Economics, No. 56, p. 377-386.

Bonnieux, F. (1989). Estimating regional-level input demand for French agriculture using a Translog production function. European Review of Agricultural Economics, Oxford University Press (OUP), p. 229-241.

Capalbo, S.M. (1985). A comparison of econometric models of US agricultural productivity and technology structure. Discussion Paper Series, RR85-O5, Resources for the Future, Washington.

Chand, R., Kumar, P. (1986). Supply Response Functions for Major Crops of Punjab in Green Revolution Period - A Profit Function Approach. Indian Journal of Economics, Vol. LXVII Part 1, July, p. 91-109.

Gregory, P.R., Rrffin, R.J. (1986). Principles of Economics. Second Edition Hardcover, Publisher: Scott, Foresman.

Griliches, Z. (1959). The demand for inputs in agriculture and a derived supply elasticity. Journal of Farm Economics, No. 41(2), p. 309-322.

Higgins, J. (1986). Input demand and output supply of Irish farms: a microeconomic approach. European Review of Agricultural Economics, Vol. 13, Issue 4, p. 477-493.

Houck, J. (1985). The link beetwen supply response and production elastities. North Central Journal of Agricultural Economics, No. 7(1), p. 11-17.

Johnson, D.G. (1950). The Nature of the Supply Function for Agricultural Products. The American Economic Review, Vol. 40, Issue 4, p. 539-564.

Jones, G.T. (1962). The response of the supply of agricultural products in the U.K. to price. Farm Economist, Vol. 10, No. 1, p. 1-15.

Kozłowski, Z. (1960). Teoria czynników produkcji w nauce ekonomiczno-rol-niczej. Zagadnienia Ekonomiki Rolnej, No. 6, p. 3-27.

Kumar, P. (1975). An Application of Generalised Least Square Estimation of Linear Regression Model with Random Coefficient to Paddy Production Function for Sambalpur District (Orissa). Indian Journal of Agricultural Economics, Vol. 30, No. 4, October-December, p. 88-102.

Kumar, P., Shinoj, P., Raju, S.S., Kumar, A., Karl, M.R., Msangi, S. (2010). Factor demand, output supply elasticities and supply projection for major crops of India. Agricultural Econonomics Research Review, No. 23(1), p. 1-14.

Lopez, R.E. (1980). The structure of production and the derived demand for inputs in Canadian agriculture. American Journal of Agricultural Economics, No. 62, p. 38-45.

Lopez, R.E. (1984). Estimating Labor Supply and Production Decisions of Self-Employed Farm Producers. European Economic Review, No. 24, p. 61-82.

Maligaya, A.R., White, F.C. (1989). Agricultural Output Supply And Input Demand Relationships With Endogenous Land Rents. Southern Journal of Agricultural Economics, Southern Agricultural Economics Association, No. 2, p. 1-8.

Pagoulatos, A., Debertin, D.L. (2015). Linkages Among Estimated Technological Parameters, Production, Supply and Input Demand Elasticities. University of Kentucky, Department of Agricultural Economics, Staff Paper No. 489.

Rayner, A.J. (1970). The demand for inputs and the aggregate supply function for agriculture. Journal of Agricultural Economics, Vol. 21, No. 2, p. 225-238.

Rembisz, W., Sielska, A. (2013). Mikroekonomia współczesna. Warszawa: Wyd. Vizja Press\&It. 
Salhofer, K. (2000). Elasticities of substitution and factor supply elasticities in European agriculture: a review of past studies. Report delivered to the Directorate for Food, Agriculture and Fisheries of the Organization for Economic Cooperation and Development in Paris, France. Retrieved from: https://wpr.boku.ac.at/wpr_dp/dp-83.pdf.

Santeramo, F.G. (2014). On the Estimation of Supply and Demand Elasticities of Agricultural Commodites. MPRA Paper No. 56126, posted 22. May 2014.

Shende, N.V., Shinde, K.J. (2010). Mathematical Modelling for demand and supply estimation. International Journal of Mathematical Sciences and Engineering Applications, 4(1), p. 251- 265.

Shumway, C.R., Villezca-Becerra, P.A. (1992). State-level output and input demand elasticities for agricultural commodities. The Journal of Agricultiural Economics Research, Vol. 44, No. 1, p. 22-34.

Sidhu, S.S., Bannante, C.A. (1981). Estimating Farm level 1 Input Demand and Wheat Supply in the Indian Punjab Using a Translog Profit Function. American Journal of Agricultural Economics, Vol. 63, No. 2, p. 237-246.

Thakare, S.S., Shende, N.V., Shinde, K.J. (2012). Mathematical Modeling for Demand and Supply Estimation for Cotton in Maharashtra. International Journal of Scientific and Research Publications, Vol. 2, Issue 3, p. 1-5.

Tomczak, F., Woś, A. (1983). Ekonomika rolnictwa. Zarys teorii. Warszawa: PWRiL.

Vukadinović, P., Damnjanović, A., Kristić-Randić, J. (2017). The analysis of indiference and the price elasticity of demand between different categories of agricultural products. Economics of Agriculture, No. 64(2), p. 671-685. 


\title{
MODELOWE UJECIE POPYTU NA CZYNNIKI WYTWÓRCZE
}

\begin{abstract}
Abstrakt
Niniejsza publikacja ma charakter teoretyczny. Podjęto w niej próbę określenia hipotetycznej relacji między podaża produkcji rolnej określonej przez dany na nia popyt z jednej strony, a popytem na czynniki zaangażowane do jej wytworzenia z drugiej strony. Ujęte jest to $w$ jednym modelu rozumowania $z$ wykorzystaniem znanych $w$ mikroekonomii prawidłowości $i$ współczynników. W szczególności wykorzystano współczynniki elastyczności popytu, podaży i produkcji. Punktem wyjścia sa założenia wynikajace z funkcji popytu i trójczynnikowej funkcji produkcji oraz o racjonalnych wyborach producentów rolnych. Na drodze analizy teoretyczno-formalnej pozytywnie zweryfikowano hipoteze, iz relacja między podaża produkcji dla danego popytu na nia a popytem na czynniki produkcji jest określona przez zmiany efektywności produkcji. Dowiedziono tego poprzez odniesienie do siebie cenowych elastyczności produkcji i podazy oraz cenowych elastyczności popytu na czynniki produkcji względem produktu. Jest to próba wypetnienia luki badawczej w tym względzie.
\end{abstract}

Słowa kluczowe: cenowa elastyczność podaży, czynnikowa elastyczność produkcji, elastyczność popytu na czynniki produkcji.

Accepted for print: 19.06.2020.

Unless stated otherwise all the materials on the website are available under the Creative Commons Attribution 4.0 International license.

Some rights reserved to the Institute of Agricultural and Food Economics - National Research Institute.

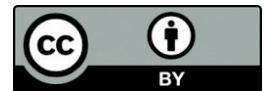

